\title{
Fraud dan Mahasiswa
}

\author{
Sigit Handoyo* \\ Ridho Dwitama
}

\begin{abstract}
Fraud commited by fraudster is aimed to take another one's or organization's assets illegally intended to take some benefit of |them. This research aims to test the level of fraud commited by University student. Samples of this research are the accounting department students studying at Universitas Islam Indonesia experienced or involved or being involved in an organization both/either in internally at Universitas Islam Indonesia and/or externally. Samples were taken by spreading of questionaires filled up by 214 students insing purpossive, sampling method. Analysis applied of this reseacrh is descriptive qualitative with fraud triagle as a basic tool to analyse which are comprised 3 push or pull factors which are perceive pressures, perceive opportunities, and perceived rasionalisation. The fundings of this research reveal that most of them experienced to commit fraud. They admit that the biggest pressure to commit fraud is the need of additional money for living costs. From perceived opportunities factor, most of them said that the weakness of internal control is the prime pull factor to commit fraud. Whilest the reality that most of their friends commit fraud is main reason or rasionalisation for them
\end{abstract}

Keywords: Fraud, fraud triangle, pressure, opportunities, rasionalization

\section{Pendahuluan}

Manusia sebagai salah satu makhluk hidup tidak terlepas dari berbagai kebutuhan, baik kebutuhan yang sifatnya material maupun kebutuhan yang bersifat spiritual. Untuk pemenuhan kebutuhan-kebutuhan ini pulalah yang melatar belakangi berbagai macam perilaku manusia, yang mernbedakannya antara satu dengan yang lain. Manusia akan merasa puas jika satu kebutuhannya sudah terpenuhi, namun merasa kurang pada sisi kebutuhan yang lain, sehingga mereka secara terus menerus akan melengkapi kebutuhan-kebutuhannya tersebut sepanjang

"Dosen Fakultas Ekonomi UiII

"* Alumni Fakultas Ekonomi UII 
hidupnya (Saleh: 2007). Maslow (1943) dalam teorinya mendefinisikan kebutuhan manusia menjadi lima.

Pertama, kebutuhan psikologis manusia yaitu kebutuhan akan makanan, minuman, tempat berlindung, dan pertolongan dari kesusahan. Kedua, kebutuhan akan keamanan yaitu kebutuhan manusia akan kebebasan dari ancaman atau keamanaan atas kejadian atau lingkungan. yang mengancam. Ketiga, kebutuhan akan rasa memiliki, sosial, dan kasih. sayang yang meliputi akan persahabatan, persatuan, interaksi dan kasih sayang. Keempat, kebutuhan manusia akan penghargaan, baik terhadap diri sendiri maupun dari orang lain. Terakhir, kebutuhan akan penunjukan diri yang sebenarnya, yaitu kebutuhan manusia untuk memenuhi diri sendiri dengan memaksimalkan penggunaan dari kemampuan, keahlian dan potensi diri.

Beragam kebutuhan diatas merupakan motivator seseorang untuk melakukan suatu tindakan nyata agar kebutuhan terpenuhi. Sayangnya, tidak semua orang dapat memenuhi kebutuhannya dengan cara yang di benarkan. Adanya hambatan hambatan seperti perbedaan kepentingan tekanan dari lingkungan keluarga maupun kerja, gaji yang rendah dan sedikitnya penghargaan yang di terima memotivasi seseorang untuk mengambil jalan pintas dengan melakukan kecurangan (Callahan: 2004).

Kecurangan merupakan bentuk dari ketidak jujuran manusia. Namun melakukan kecuarangan merupakan suatu pilihan bagi sebagian orang yang berada dalam kondisi tedesak oleh besarnya hambatan yang harus di hadapi. Situasi seperti ini mungkin saja terjadi di tengah lingkungan kita khususnya ketika kita terdapat sebagian orang yang merasa bahwa kejujuran itu bersifat situasional. Kita sering mendengar maupun membaca artikel dan berita mengenai adanya indikasi fraud atau kecurangan/penyimpangan pada suatu perusahaan atau instansi pemerintah yạng dilakukan oleh karyawan/pegawainya. Walaupun saat ini sorotan utama sering terjadi pada manajemen puncak perusahaan, atau terlebih lagi terhadap pejabat tinggi suatu instansi, namun sebenarnya penyimpangan perilaku tersebut bisa juga terjadi di berbagai lapisan kerja organisasi.

Pada dasarnya memang benar tetapi tindakan kecurangan ini merupakan awal dari seseorang untuk melakukan tindakan seperti korupsi. Wilopo (2007) menjelaskan bahwa dalam korupsi, tindakan yang lazim dilakukan di antaranya adalah manipulasi pencatatan, penghilangan dokumen, dan mark-up yang merugikan keuangan negara atau perekonomian negara. Jawaban sederhana yang menjelaskan korupsi karena: "corruption (atau fraud) by need, by greed and by opportunity", korupsi karena kebutuhan, karena serakah dan karena ada peluang. Tuanakotta (2007). 


\section{Tinjauan Pustaka}

Fraud merupakan salah sàtu bentuk irregularities. Secara singkat, fraud dinyatakan sebagai suatu penyajian yang palsu atau penyembunyian fakta yang material yang menyebabkan seseorang memiliki sesuatu. Pada penelitian yang dilakukan oleh Donald R. Cressey mengenai Fraud Examiners Manual (2006) yang di tuliskan di dalam buku Tuanakotta (2007) bahwa mereka yang melanggar , kepercayaan atau amanah yang dititipkan kepada mereka di sebut dengan "trust violators" atau "pelanggar kepercayaan", yang menyerah dengan kepada godaan.

Ada pula yang mendefinisikan Fraud yaitu Menurut Singleton èt al. (2006), fraud atau kecurangan yang disengaja merupakan strategi untuk mencapai tujuan personal atau organisasi atau untuk memenuhi kebutuhan seseorang. Fraud juga diartikan sebagai aktivitas yang belangsung di lingkungan sosial dan memiliki konsekuensi berat bagi ekonomi, korporasi, dan individu (Sivertone, et. Al: 2004). Dengan demikian perbuatan yarig dilakukannya adalah untuk menyembunyikan, menutupi atau dengan cara tidak jujur lainnya melibatkan atau meniadakan suatu perbuatan atau membuat pernyataan yang salah dengan tujuan untuk mendapatkan keuntungan pribadi di bidang keuangan (Suhermadi: 2006).

\section{Klasifikasi Fraud}

Dari bagan Uniform Occupational Fraud Classification System tersebut, The ACFE (Association of Certified Fraud Examinations) mengkategorikan Fraud ke dalam tiga kelompok jenis atau tipologi berdasarkan perbuatan yaitu:

a. Penyimpangan atas asset (Asset Misappropriation);

Asset missappropriation atau yang disebut juga dengan pengambilan meliputi penyalahgunaan aset atau harta perusahaan atau pihak lain yang dilakukan ' oleh seseorang yang diberi wewenang untuk mengelola atau mengawasi asset tersebut, disebut menggelapkan. Di dalam Asset misappropriation dalam bentuk penjarahan cash atau Cash Missappropriation dilakukan dalam tiga bentuk: skimming, larcency, dan fraudulent disbursement (Tuanakotta, 2007).

- Dalam skimming, uang dijarah sebelum uang tersebut secara fisik masuk ke perusahaan. Cara ini terlihat dalam fraud yang sangat dikenal para auditor, yaitu lapping. Kalau uang sudah masuk ke perusahaan dan kemudian baru dijarah, maka, fraud ini disebut larceny atau pencurian.

- Laceny atau pencurian adalah bentuk penjarahan jenis ini berkaitan erat dengan lemahnya sistem pengendalian intern, khususnya yang berkenaan dengan perlindungan keselamatan asset (safeguarding of assets).

- Pencurian melalui pengeluaran yang tidak sah (fraudulent disbursement) sebenarnya satu langkah lebih jauh dari pencurian. Sebelum tahap pencurian, ada tahap perạtara sebagai berikut: Billing Schemes, Payroll 
Scheme, Expense Rimbursement Scheme, Check Tampering, dan Register Disbursements.

- Billing Schemes adalah skema permainan (schemes) dengan menggunakan proses billing atau pembebanan tagihan sebagai sasarannya..

- Payroll Scheme adalah bentuk permainannya antara lain dengan pegawai atau karyawan fiktif (ghost employee). Atau dalam pemalsuan jumlah gaji. Jumlah gaji dilaporkan lebih besar dari gaji yang dibayarkan.

- Expense Rimbursement Scheme adalah skema permainan melalui pembayaran, misalnya biaya perjalanan salesman mengambil uang muka

.. perjalanan, dan sekembalinya dari perjalanan ia membuat perhitungan jumlah biaya perjalanan.

- Check Tampipering adalah skema permaianan melalui pemalsuan cek. Yang dipalsukan bisa tandatangan orang yang mempunyai kuasa pengeluaran cek, atau endorsemennya, atau nama kepada siapa cek. dibayarkan, atau ceknya disembunyikan (concealed checks).

- Register Disbursements adalah pengeluaran yang sudah masuk dalam cash register. Skema permainan melalui register disbursements pada dasarnya ada dua, yakni false refunds (pengembalian uang yang dibuat-buat) dan false refunds (pembatalan palsu).

b. Pemyataan palsu atau salah pernyataan (Fraudulent Statement);

Fraudulent statement meliputi tindakan yang dilakukan oleh pejabat atau eksekutif suatu perusahaan atau instansi pemerintah untuk menutupi kondisi keuangan yang sebenarnya dengan melakukan rekayasa keuangan (financial engineering) dalam penyajian laporan keuangannya untuk memperoleh keuntungan atau mungkin dapat dianalogikan dengan istilah window dressing.

\section{c. Korupsi (Corruption).}

Korupsi umumnya didefinisikan sebagai penyalahgunaan jabatan di sector pemerintahan untuk kepentingan pribadi. Korupsi yang didefinisikan seperti itu meliputi misalnya, penjualan kekayaan negara secara tidak sah oleh pejabat. Jenis fraud ini yang paling sulit dideteksi karena menyangkut kerja sama dengan pihak lain seperti suap dan korupsi, di mana hal ini merupakan jenis yang terbanyak terjadi di negara-negara berkembang yang penegakan hukumnya lemah dan masih kurang kesadaran akan tata kelola yang baik sehingga faktor integritasnya masih dipertanyakan. 
Sigit Handoyo \& Ridho Dwitama, Fraud Dan Mahașiswa

\section{Gambar 1}

\section{Fraud Tree}

\section{Fraud Tree}
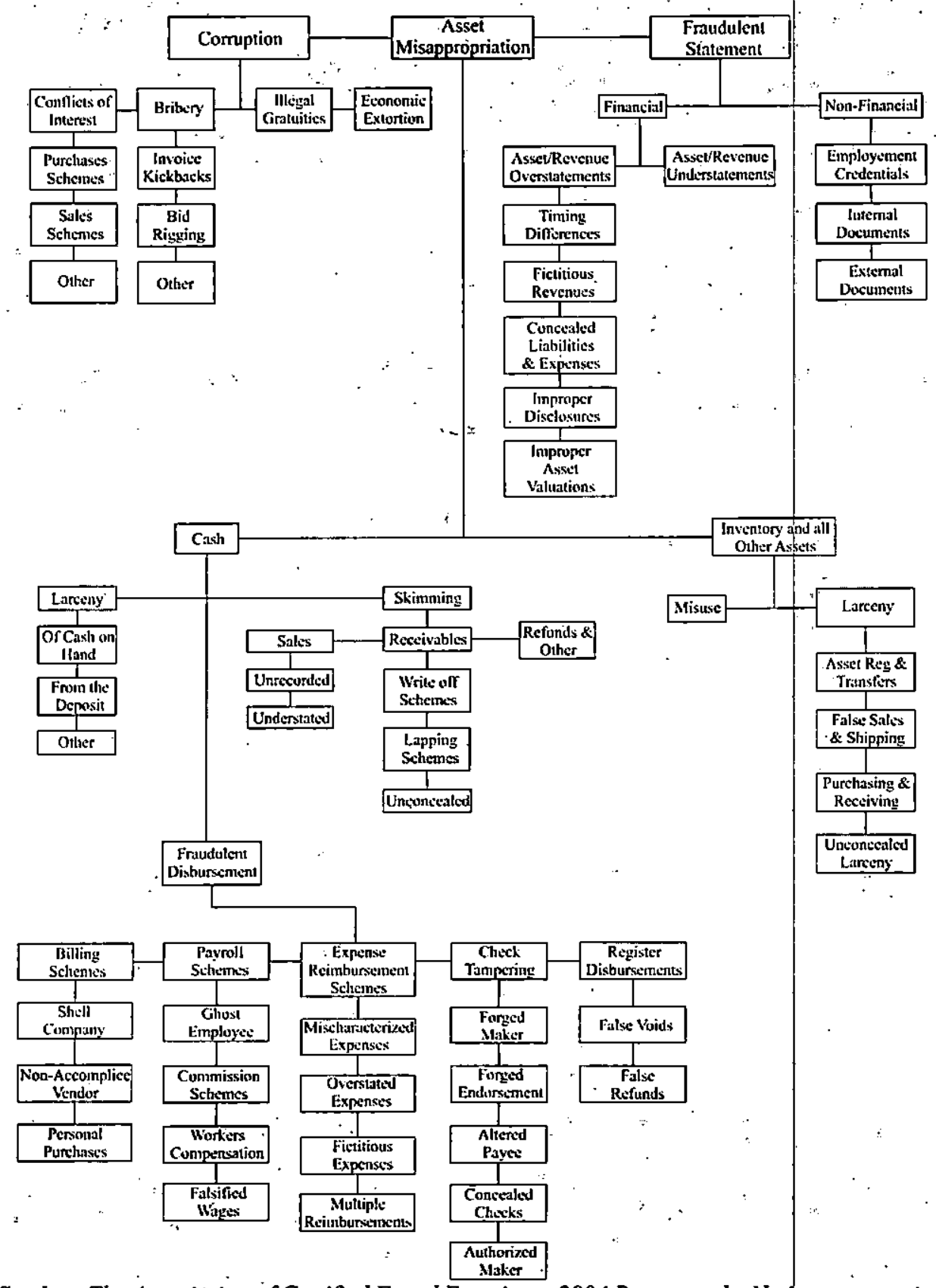

Sumber: The Association of Certified Fraud Examiners 2004 Report to the Nation on Occupational Fraud and Abuse 


\section{Unsur-Unsur terjadinya Fraud}

Pemicu sebuah tindakan fraud terdiri dari unsur-unsur penting yang digunakan untuk menguji tanda-tanda fraud atau tidak. Di lihat dari pusdiklatwas (BPKP: 2008) Tindakan fraud ini juga merupakan gabungan dari motivasi dan kesempatan yang menyebabkan seseorang melakukan sebuah tindakan seperti "Adanya penipuan, adanya penyembunyian fakta, dan adanya pemanfaatan hasil oleh perusahaan atau individu." Dari pernyataan tersebut, dapat disimpulkan fraud terjadi apabila terdiri dari unsur-unsur berikut ini:

Korban fraud menderita kehilangan hak milik atau uang karena telah mempercayai dan bertindak sesuai dengan penyajian yang keliru tersebut.

Adanya unsur kesengajaan dari individu atau organisasi untuk membuat penyajian yang keliru mengenai peristiwa atau fakta yang penting.

Adanya kerugian atau keuntungan dalam jumlah material bagi perusahaan.

\section{Faktor Pemicu Fraud (Kecurangan)}

Terdapat empat faktor pendorong seseorang untuk melakukan kecurangan,yang disebut juga dengan teori GONE (Simanjuntak: 2001), yaitu:

- Greed (keserakahan)

- Opportunity (kesempatan)

- Need (kebutuhan)

- Exposure (pengungkapan)

Faktor Greed dan Need merupakan faktor yang berhubungan dengan individu pelaku kecurangan (disebut juga faktor individual). Sedangkan faktor Opportunity dan Exposure merupakan faktor yang berhubungan dengan organisasi sebagai korban perbuatan kecurangan (disebut juga faktor generik/umum).

1. Faktor generik

- Kesempatan (opportunity) untuk melakukan kecurangan tergantung pada kedudukan pelaku terhadap objek kecurangan. Kesempatan untuk melakukan kecurangan selalu ada pada setiap kedudukan. Namun, ada yang mempunyai kesempatan besar dan ada yang kecil. Secara umum manajemen suatu organisasi/perusahaan mempunyai kesempatan yang lebih besar untuk melakukan kecurangan daripada karyawan;

- Pengungkapan (exposure) suatu kecurangan belum menjamin .tidak terulangnya kecurangan tersebut baik oleh pelaku yang sama maupun oleh pelaku yang lain. Oleh karena itu, setiap pelaku kecurangan seharusnya dikenakan sanksi apabila perbuatannya terungkap: 


\section{Faktor individu}

Faktor ini melekat pada diri seseorang dan dibagi dalam dua kategori:

- Moral, faktor ini berhubungan dengan keserakahan (greed). Beberapa hal yang perlu dipertimbangkan untuk mengurangi risiko tersebut adalah misi/tujuan organisasi/perusahaan, ditetapkan dan dicapai dengan melibatkan seluruh pihak (manajemen dan karyawan) dengan membuat aturan perilaku pegawai, dikaitkan dengan lingkungan dan budaya organisasi/perusahaan;

- Motivasi, faktor ini berhubungan dengan kebutuhan (need), yang lebih cenderung berhubungan dengan pandangan/pikiran dan keperluan pegawai/pejabat yang terkait dengan aset yang dimiliki perusahaan/instansi/organisasi tempat ia bekerja. Selain itu tekanan (pressure) yang dihadapi dalam bekerja dapat menyebabkan orang yang jujur mempunyai motif untuk melakukan kecurangan.

\section{Faktor-Faktor Pendorong Orang Melakukan Fraud (Triangle Fraud)}

Ada 3 faktor yang membuat seseorang dalam melakukan tindakan kecurangan (fraud). Menurut Buckhoff (2001) faktor pertama dari triangle fraud adalah kesempatan. Banyak organisasi yang tanpa sadar bahwa mereka telah membuat organisasi tetapi yang didalamnya ada kesempatahn yang mudah untuk dilakukan kecurangan. Ini mungkin bisa dikatakan karena kurangnnya kontrol dari organisasi itu sendiri. Faktor yang kedua adalah tekanan. Unsur ketiga dan terakhir dari fraud triangle ini adalah rasionalisasi, yang beranggapan bahwa tìndakan yang ia lakukan benar. Sedangkan menurut Tuanakotta fraud umumnya terjadi karena adanya tekanan untuk melakukan penyelewengan atau-dorongan untuk memanfaatkan kesempatan yang ada dan adanya pembenaran (Tuanakotta: 2007) diterima secara umum terhadap tindakan tersebut. Ada 3 hal yang mendorong terjadinya sebuah upaya fraud, yaitu pressure (dorongan), opportunity (peluang), dan rationalization (rasionalisasi), sebagaimana tergambar berikut ini:

\section{Gambar 2}

Fraud Triangle

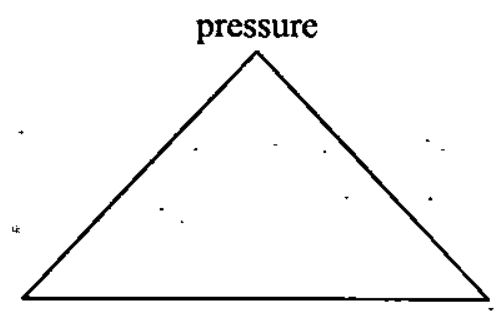

opportunity

rationalization 


\section{Pressure}

Pressure adalah dorongan yang menyebabkan seseorang melakukan fraud, contohnya hutang atau tagihan yang menumpuk, gaya hidup mewah", ketergantungan narkoba, dan lain-lain. Sebagian besar tekanan yang timbul dari seseorang meliputi tekanan akan kebutuhan keuangan ataupun tekanan nonkeuangan, 'seperti kebutuhan untuk melaporkan hasil yang lebih baik dari pada kinerja aktualnya, frustasi dengan pekerjaan, atau bahkan tantangan untuk melawan sistem, juga dapat memotivasi untuk melakukan fraud (Albrecht et al., 2006). Apa yang di alami fraudster dalam kehidupan pribadinya atau kebiasaan hidup dapat menjadikan itu sebagai tekanan yang dimana akan menimbulkan motivasi untuk melakukan 'penipuan'. Ke semua tekanan ini akan memungkinkan fraudster untuk mencari kepuasaan atas keserakahannya, tingkat kepuasaan yang tidak terbatas dalam diri fraudster itulah yang menyebabkan orang-orang kaya atau berkuasa. melakukan fraud. Disini juga menemukan bahwa non-shareable problems yang dihadapi orang-orang yang diwawancarainya timbul dari situasi yang dapat dibagi menjadi enam kelompok (tuanakota: 2007):

- Violation of ascribed obligation: merupakan suatu kedudukan atau jabatan dengan tanggung jawab keuangan, membawa konsekuensi tertentu bagi yang bersangkutan dan juga menjadi harapan atasan atau majikannya. Di samping harus jujur, ia dianggap memiliki perilaku tertentu. Disini perilaku yang harus dihindari perbuatan seperti berjudi, mabuk menggunakan narkoba dan perbuatan lain yang merendahkan martabatnya.

- Problems resulting from personal failure: kegagalan pribadi juga merupakan situasi yang diperșepsikan oleh orang yang mempunyai kedudukan yang dipercaya dalam bidang keuangan, sebagai sebagai kesalahannya menggunakan akal sehatnya, dank arena itu menjadi tanggung jawab pribadinnya. Banyak perilaku dari seseorang yang timbul dikarenakan takut kehilangan statusnya sebagai orang yang dipercaya, karena ia takut kehilangan statusnya dan mengakui kegagalan, sekalipun kepada orang-orang yang sesungguhnyadapat membantunya, dan ia memilih untuk mencuri. Kehormatan pada diri sendiri menjadi awal kejatuhannya.

- Business reversals: menyimpulkan bahwa kegagalan bisnis merupakan kelompok situasi yang juga mengarah kepada non- shared problems. Masalah ini berbeda dari kegagalna pribadi yang di jelaskan di atas, karena pelakunnya merasa kegagalan itu berada di luar dirinya atau di luar kendalinnya. Dalam presepsinya, kegagalan itu karena inflasi yang tinggi, atau krisis moneter/tingkat bunga yang tinggi dan lain-lain.

- Physical isolation: secara bebas, situasi ini dapat diterjemahkan sebagai keterpurukan dalam sendirian. Dalam situasi seperti ini orang tersebut bukan' 
tidak mau membagi keluhan kepada orang lain. Ia tidak mempunyai orang lain untuk ia mengungkapkan masalahnya. Sebagai contọ tekanan yang ia dapat ialah baru kehilangan seperti orang yang ia cintai seperti kematian istri yang tidak mampu di ungkapkan masalah keuangannya kepada orang lain.

- Status gaining: situasi kelima ini tidâk lain dikarenakan atas kebiasaan buruk untuk tidak mau kalah baik dari tetangga atau orang-orang yang ada di sekelilingnya. Orang lain punya harta tertentu, ia juga harus seperti itu atau lebih baik. Dalam situasi seperti ini pelaku mempertahankan status. Di sini, pelaku berusaha meningkatkan statusnya.

- Employer-employee relations: umumnya pada situasi keenam ini menjelaskan perilaku seseorang berasal dari rasa kebenciaanya atau kekesalannya terhadap situasi jabatan yang ia pegang sekarang, tetapi pada saat yang sama ia merasa tidak ada pilihan baginnya, yakni ia harus tetap menjalankan apa yang menjadi pekerjaannya sekarang. Kekesalan itu bisa terjadi karena ia merasa gaji atau imbalan lainnya tidak layak atas pekerjaan atau kedudukannya, atau ia merașa beban pekerjaannya teramat banya, atau ia merasa kurang mendapat penghargaan batiniah (pujian).

\section{Opportunity}

Opportunity adalah peluang atau kesempatan yang memungkinkan fraud terjadi di lingkungan organisasi. Biasanya disebabkan karena internal control suatu organisasi yang lemah, kurangnya - pengawasan, dan/atau penyalahgunaan wewenang. Menurut Cressey, ada dua komponen dari persepsi peluang. Pertama general information, yang merupakan pengetahuan ini diperoleh dari|apa yang ia dengar atau. Kedua, technical skill ini biasanya keahlian atau ketrampilan yang dipunyai orang itu dan yang menyebabkan ia mendapat kedudukan tersebut dari posisi ia bekerja.

\section{Rationalization}

Rasionalisasi menjadi elemen penting dalam terjadinya fraud, dimana pelaku mencari pembenaran atas tindakannya. Rationalization diperlukan agar si pelaku dapat mencerna perilakunya yang illegal untuk tetap mempertahankan jati dirinya sebagai orang yang di percaya. Setelah kejahatan dilakukan, rationalization ini di tinggalkan, karena tidak di perlukan lagi. Ada pun alasan yang lain seseorang melakukan kecurangan dengan pembenaran misalnya bahwasanya tindakannya untuk membahagiakan keluarga dan orang orang yang dicintainya.

\section{Pencegahan Fraud}

Didalam organisasi sebuah kucarangan biasanya dapat dicegah dengan Biasanya penipuan dicegah dengan sebuah pengendalian internal, dan menciptakan 
gaya kepemimpinan yang baik didalam organisasi tersebut (Ulinsky: 2007). Adapun langkah-langkah mencakup:

- Pengembangan lingkungan pengendalian, yang dimulai dari kesadaran tentang perunya pengendalian.

- Penetapan sasaran tujan organisasi yang realistis.

- Menetapkan aturan perilaku, mana aturan yang tidak boleh dan mana aturan yang tidak.

- Kebijakan dan otorisassi organisasi yang tepat untuk setiap transaksi terus diwujudkan dan di pelihara.

- Kebijakan, praktik, prosedur, dan pelaporan dan mekanisme lainnya untuk memonitor aktivitas didalam organisasi.

- Mekanisme komunikasi yang dapat dipercaya serta berkesinambungan antara seluruh organisasi.

\section{Metode Penelitian}

Pada bagian ini akan diuraikan metode penelitian yang mencakup populasi, penentuan sample, sumber data dan model penelitian.

\section{Populasi dan sampel}

Secara umum populasi dapat didefinisikan sebagai sekumpulan data yang mengidenfikasi suatu fenomena. Pengertian populasi menurut Sugiyono (2009) adalah wilayah generalisasi yang terdiri atas objek atau ssubyek yang mempunyai kualitas dan karakteristik tertentu yang ditetapkan oleh peneliti untuk dipelajari dan kemudian ditarik kesimpulan. Populasi penelitian ini adalah para mahasiswa Jurusan Akuntansi Universitas Islam Indonesia dan yang sudah pernah terlibat di dalam organisasi atau suatu kepanitiaan baik di dalam maupun di luar lingkunganUniversitas Islam Indonesia.

Sampel menurut Sugiyono (2009) adalah sebagian individu atau populasi yang diselidiki. Dapat disimpulkan bahwa sampel adalah sebagian populasi yang diambil untuk diselidiki oleh peneliti. Sedangkan pengertian menurut Satori (2011) sampel adalah sekumpulan data yang di ambil atau diseleksi dari suatu populasi. Pengambilan sampel menggunakan purposive sampling. Purposive sampling dilakukan dengan menggunakan sampling yang terpilih betul oleh peneliti menurut kriteria khusus. Sampel yang di ambil di merupakan mahasiswa akuntansi yang telah menempuh 1 atau 8 semester. Pengambilan sampel dalam penelitian ini digunakan 214 sampel dengan memberikan pertanyaan melalui kusioner kepada responden, setelah diisi kuisioner langsung diserahkan kepada penulis. 


\section{Sumber Data'}

Teknik yang. digunakan untuk memperoleh data adalah dengan menyebarkan kuisioner kepada mahasiswa dengan memberikan daftar pertanyaan secara langsung kepada responden. Setelah diisi, kuisioner langsung diserahkan 'kembali secara langsung kepada penulis.

\section{Model Penelitian}

Analisa data kualitatif berlangsung selama dan setelah pengumpulan data. Dalam penelitian ini analisis selama di lapangan menggunakan model Miles dan Huberman (sugiyono: 2009) dan mengemukakan bahwa aktivitas dalam analisis data kualitatif dilakukan secara interaktif dan berlangsung secara terus menerus sampai tuntas, sehingga datanya sudah jenuh. Aktivitas dalam analisis memfokuskan pada hal-hal yang penting, dicari tema dan polanya. Mencari hubungan antar domain, dan bagaimàna hubungan dengan keseluruhan, dan selanjutnya dinyatakan ke dalam tema/judul penelitian. Data display adalah aktivitas penyajian data dalam bentuk uraian singkat, bagan, hubungan antar kategori, flowchart dan sejenisnya. Conclusion drawing adalah aktivitas penarikan kesimpulan dan verifikasi. Kesimpulan dalam penelitian kualitatif mungkin dapat menjawab rumusan masalah yang dirumuskan sejak awal, tetapi mungkin juga tidak, karena masalah dan rumusan masalah dalam penelitian kualitatif masih bersifat sementara dan akan berkembang setelah peneliti berada di lapangan.

\section{Hasil Analisa Tindakan Kecurangan Atau Fraud}

Berikut ini adalah gambar hasil persentase dari butir item yang telah dikumpulkan melalui angket atau kuisioner:

Gambar 3

Tindak Kecurangan atau Fraud yang sering dilakukan

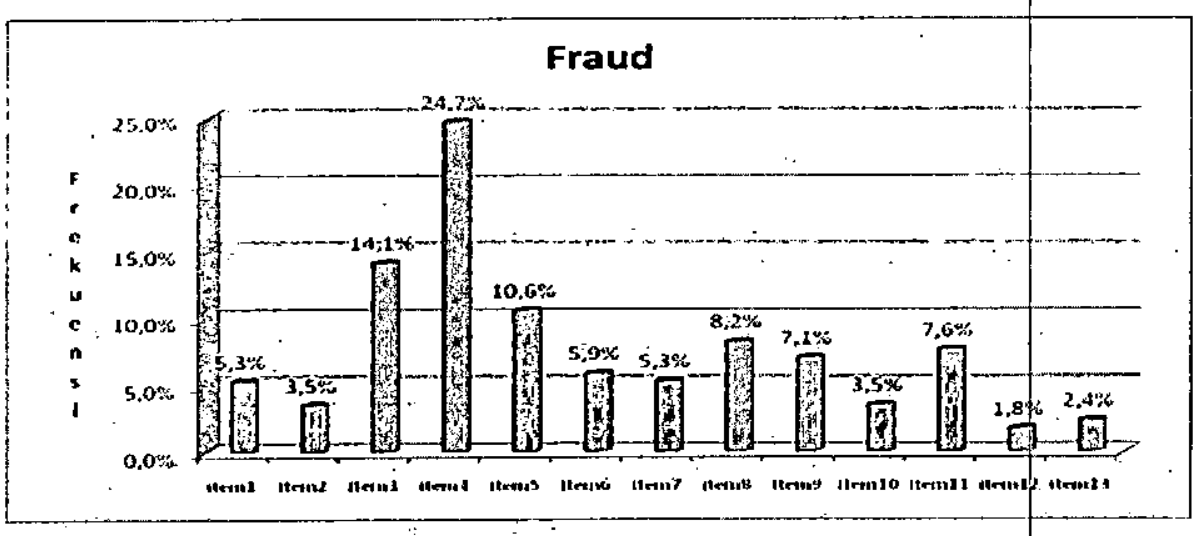


Berdasarkan tindak kecurangan dari gambar di atas; maka dapat dijelaskan bahwa tindak kecurangan yang paling sering dilakukan oleh para mahasiswa khususnya mahasiswa Jurusan Akuntansi Fakultas Ekonomi Universitas Islam Indonesia Yogyakarta adalah pada item 4 yaitu membuat nota transaksi sendiri (palsu) untuk pelaporan yaitu sejumlah $24,7 \%$, kemudian diikuti tindakan kecurangan pada item 3 yaitu tentang Mengganti angka pada nota transaksi untuk pelaporan kepanitiaan atau organisasi sebesar $14,1 \%$, pada item 5 sejumlah $10,6 \%$ yaitu dengan tindakan meminjam uang dari teman dan tidak saya kembalikan dan kemudian yang paling sedikit kecurangan dilakukan adalah pada item 12 yaitu tentang meminta uang untuk pembayaran spp di atas yang ditetapkan, baik dari lembaga maupun organisasi tempat saya mendapatkan biaya tersebut.

\section{Deskripsi Pembahasan}

Pada persentase yang didapat pada item 4 dengan tindakan membuat nota transaksi sendiri (palsu) untuk pelaporan adalah salah satu tindakan pencurian pengeluaran yang tidak sah (cash disbursement) atau penggelapan dengan tindakan untuk menutupi kondisi keuangan yang sebenarnya, dengan menciptakan transaksi palsu.

\section{Hasil Analisa Fraud Triangle}

Berikut akan diuraikan 3 hal yang mendorong terjadinya sebuah upaya melakukan fraud didalam organisasi, yaitu pressure (dorongan), opportunity (peluang), dan rationalization (rasionalisasi) sebagaimana berikut ini:

\section{Pressure (dorongan)}

Pressure merupakan dorongan yang menyebabkan seseorang melakukan fraud. Pada umumnya yang mendorong terjadinya fraud adalah kebutuhan atau masalah finansial. Tapi banyak juga yang hanya terdorong oleh keserakahan. Manajemen atau karyawan mungkin memiliki dorongan atau tekanan yang menjadi alasan melakukan kecurangan. Untuk melakukan kecurangan lebih banyak tergantung pada kondisi individu, seperti sedang menghadapi masalah.keuangan, kebiasaan buruk seseorang seperti berjudi dan peminum, atau mempunyai harapan/tujuan yang tidak realistik. Salah satu yang menjadi contoh ialah penggelapan uang perusahaan bermula dari suatu tekanan (pressure) yang menghimpitnya.

Berikut ini adalah gambar hasil persentase dari butir item yang telah dikumpulkan melalui angket atau kuisioner: 
Sigit Handoyo \& Ridho Dwitama, Fraud Dan Mahasiswa

Gambar 4

Faktor Pressure yang Menyebabkan Fraud

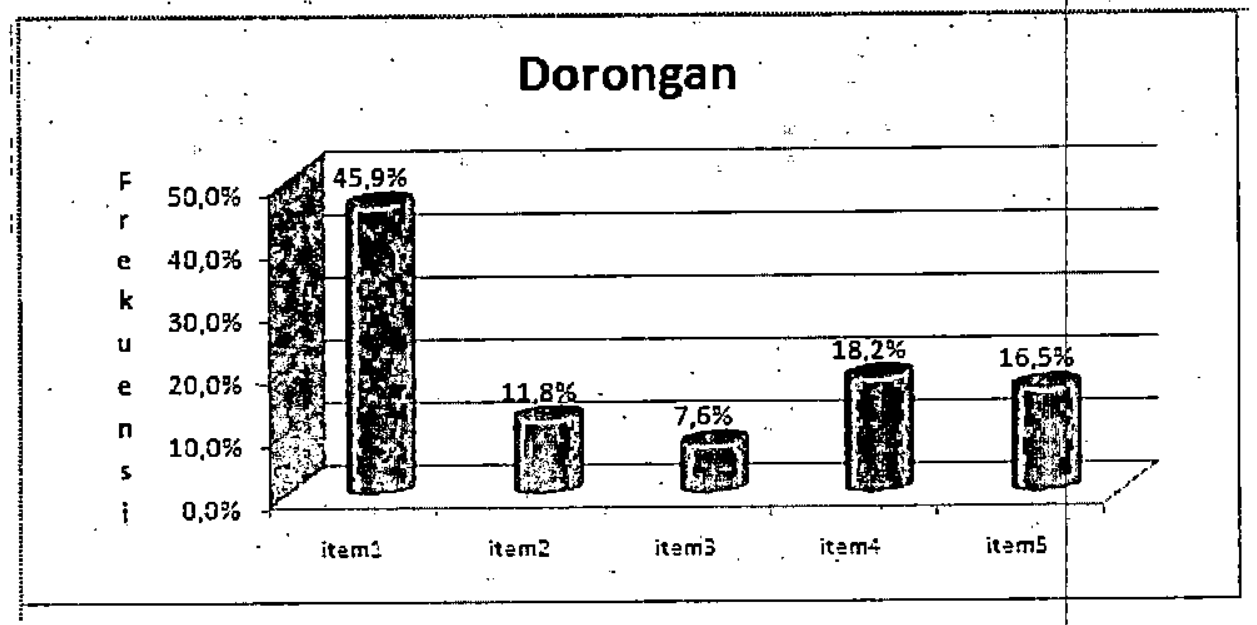

Berdasarkan faktor dorongan, maka dapat dijèlaskan bahwa responden dalam melakukan tindak kecurangan lebih banyak dikarenakan pada item 1 yaitu tentang membutuhkan tambahan biaya hidup dengan faktor dorongan sebesar $45,9 \%$, kemudian diikuti oleh faktor dorongan pada item 4 yaitu tentang melakukan tindakan kecurangan karena ajakan atau bujukan dari teman yaitu sebesar $18,2 \%$, dan pada item 5 yaitu saya melakukan tindakan tersebut ingin mengikuti gaya hidup zaman sekarang yaitu sebesar $16,5 \%$ dan yang paling sedikit adalah pada item 3 yaitu tentang dorongan melakukan tindakan kecurangan karena tagihan yang menumpuk yaitu sebesar $7,6 \%$.

\section{Pembahasan Mengenai Tekanan}

Pada dasarnya seseorang melakukan fraud juga dipengaruhi faktor tekanan atau dorongan. Dari deskripsi preassure atau tekanan diatas pada item 1 yaitu tentang membutuhkan tambahan biaya hidup dengan faktor dorongan sebesar $45,9 \%$ seseorang melakukan tindakan kecurangan ini bisa juga di karenakan seperti membutuhkan biaya hidup, hutang menumpuk yang harus dilunasi, ajakan atau bujukan dari teman dan mengikuti gaya hidup zaman sekarang. Masalah-masalah ini timbul bisa dikarenakan (Tuanakotta: 2007):

Problems resulting from personal failure: adalah kegagalan pribadi juga merupakan situasi yang di persepsikan oleh orang yang mempunyai kesalahannya menggunakan akal sehatnya. Tekanan atas kegagalan pribadi juga bisa membuat seseorang kehilangan status sebagai orang yang dipercaya yang mengakibatkan seseorang melakukan tindakan-tindakan seperti mencuri. 
- Status gaining: bisa di jelaskan dan di golongkan bahwa tekanan-tekanan yang terjadi adalah harta. Orang lain punya harta tertentu dan dia juga harus seperti itu, seseorang berusaha bagaimana dia bisa membuat dirinnya tidak ketinggalan pada orang lain dan berusaha mengikuti gaya hidup zaman sekarang.

\section{Opportunity (peluang)}

Opportunity (peluang) merupakan peluang yang menyebabkan seseorang melakukan fraud. Biasanya disebabkan karena internal control suatu organisasi yang lemah, kurangnya pengawasan, dan/atau penyalahgunaan wewenang. Berikut ini adalah gambar hasil persentase dari butir item yang telah dikumpulkan melalui angket atau kuisioner:

Gambar.5

Faktor Opportunity (peluang) yang Menyebabkan Fraud

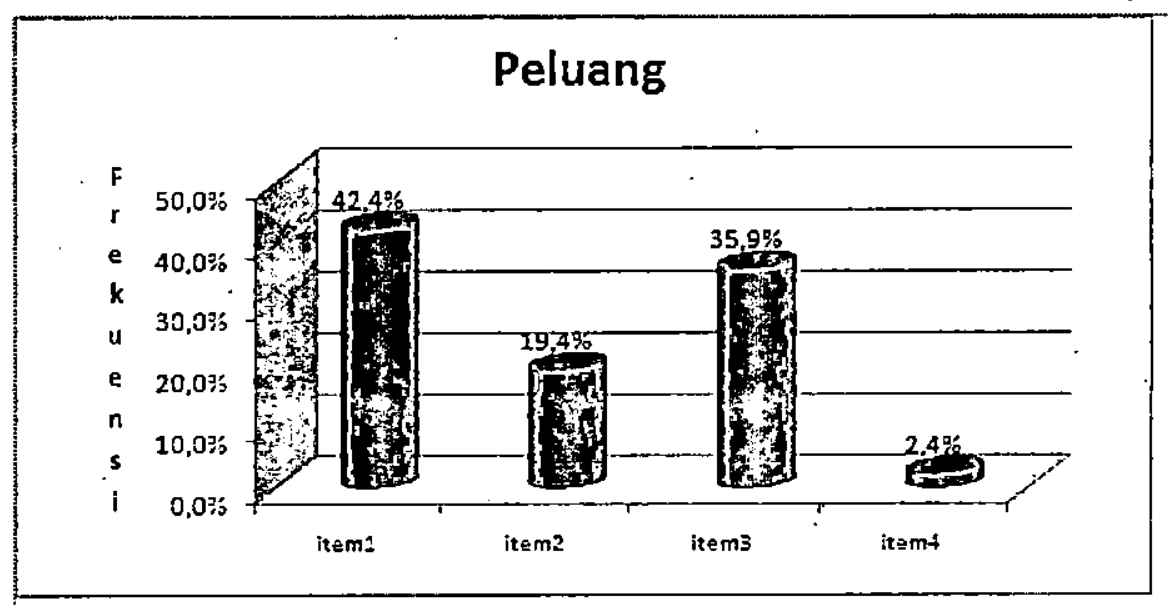

Berdasarkan faktor peluang, maka dapat dijelaskan bahwa responden dalam melakukan tindak kecurangan lebih banyak dikarenakan pada item 1 yaitu tentang melakukan tindakan kecurangan dikarenakan tidak ada pengawasan yang baik dari organisasi atau kepanitiaan dengan faktor peluang sebesar $42,4 \%$, kemudian diikuti oleh faktor peluang pada item 3 yaitu tentang melakukan tindakan kecurangan karena tidak pernah diadakannya pemeriksaan di organisasi atau kepanitiaan yaitu sebesar 35,9. 


\section{Pembahasan Mengenai Peluang}

Berdasarkan data deskripsi diatas mengenai faktor peluang; biasanya disebabkan karena internal control suatu organisasi yang lemah, kurangnya pengawasan, dan/atau penyalahgunaan wewenang; tidak adanya pengecekan dari organisasi atau kepanitiaan, dan teman yang menjadi sasaran tidak terlalu memperhatikan barang yang menjadi kepemilikannya. Di antara 3 elemen fraud triangle, opportunity merupakan elemen yang paling memungkinkan untuk diminimalisir melalui penerapan proses, prosedur, dan control dan upaya deteksi dini terhadap fraud. Pada item 1 yaitu tentang melakukan tindakan kecurangan dikarenakan tidak ada pengawasan yang baik dari organisasi atau kepanitiaan dengan faktor peluang sebesar $42,4 \%$ ini bisa terjadi karena adanya kesempatan untuk melakukan kecurangan tergantung pada kedudukan pelaku terhadap objek kecurangan yang akan dilakukan. Kesempatan untuk melakukan kecurangan selalu ada pada setiap tindakan namun, ada yang mempunyai kesempatan besar. dan ada yang kecil. Ini juga bisa dikarenakan adanya masalah pada seseorang sehingga dia menunggu kesempatan untuk melakukan tindakan kecurangan tersebut Masalahmasalah ini timbul bisa dikarenakan (Tuanakotta: 2007):

- General information: disini pelaku mencari informasi terhadap pelaku-pelaku fraud sebelumnya, apakah tindakan tersebut tidak ketahuan, tidak dihukum dan terkena sangsi didalam organisasi dan suatu kepanitiaan tempatnya melakukan kecurangan tersebut.

- Technical skill: disini dapat disimpulkan bahwa pelaku tindakan kecurangan menggunakan keahlian dan keterampilan yang dibutuhkan untuk melaksanakan kejahatan tersebut. Bisa saja awalnya pelaku tindakan tersebut sudah diberi kepercayaan seperti pingisian cek yang akan ditandatangani atasannya. Atau bisa saja pelaku tindakan tersebut sudah merasa akrab dengan teman yang menjadi sasarannya, dan teman tersebut merasa percaya pada dirinya.

\section{Rationalization (rasionalisasi)}

Rationalization (rasionalisasi) menjadi elemen penting dalam terjadinya fraud, dimana pelaku mencari pembenaran atas tindakannya, mencari pembenaran sebenarnya merupakan bagian yang harus ada di kejahatan itu sendiri, bahkan merupakan bagian dari motivasi untuk melakukan kejahatan. Rationalization diperlukan agar apa yang dilakukan si pelaku dapat diterima alasannya jika hal itubukanlah sebuah tindakan kecurangan (fraud). Setelah kejahatan dilakukan, rationalization ini di tinggalkan, karena tidak di perlukan lagi. Ini naluri alamiah 
kita. Berikut ini adalah gambar hasil persentase dari butir item yang telah dikumpulkan melalui angket atau kuisioner:

\section{Gambar.4.5.5}

\section{Faktor Rationalization (rasionalisasi) yang Menyebabkan Fraud}

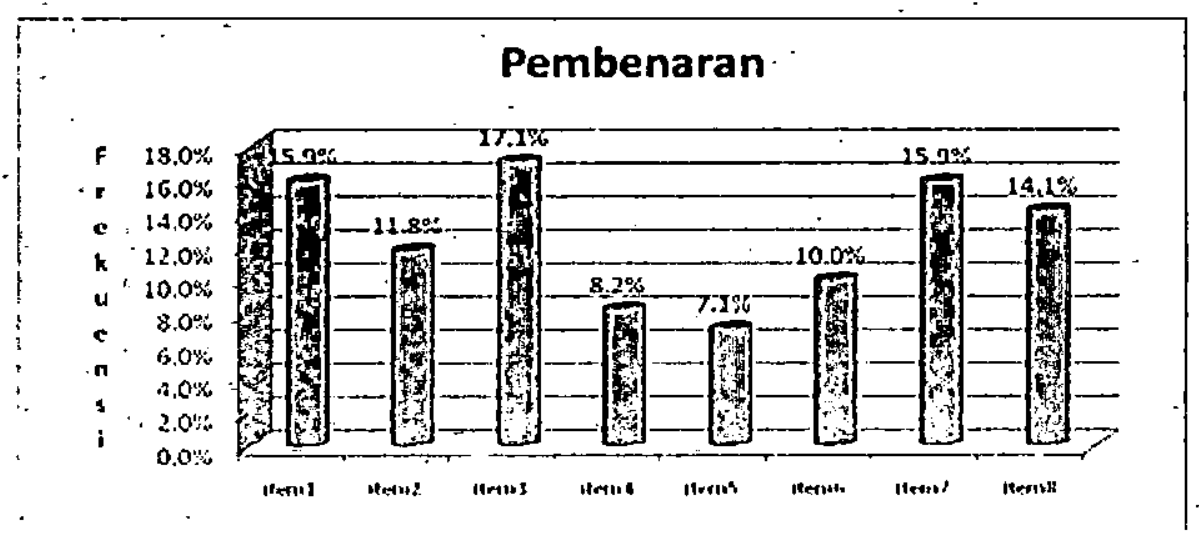

. Berdasarkan faktor rasionalisasi, maka dapat dijelaskan bahwa responden dalam melakukan tindak kecurangan lebih banyak dikarenakan pada item 3 yaitu tentang melakukan pemalsuan dokumen karena teman-teman yang lain di organisasi juga melakukan dengan faktor rasionalisasi sebesar $17,1 \%$, kemudian diikuti oleh faktor rasionalisasi pada item 1 yaitu tentang melakukan tindakan kecurangn karena hanya meminjam barang milik teman. untuk di gadaikan dan suatu saat akan saya kembalikan yaitu sebesar $15,9 \%$ dan yang paling sedikit adalah pada item 5 yaitu tentang rasionalisasi melakukan tindakan kecurangan dengan melakukan pemalsuan pada nota transaksi karena teman-teman juga melakukan yaitu sebesar $7,1 \%$.

\section{Pembahasan Mengenai Rasionalisasi}

Bagian pembenaran ini seharusnya merupakan yang dibutuhkan daläm tindakan fraud. Dalam kaitan dengan deskripsi diatas masalah ini timbul dikarenakan (Tuanakotta: 2007):

- Pelaku disini mencari pembenaran pada suatu organisasi atau kepanitian. Pelaku beranggapan bahwa teman-teman juga melakukan pemalsuan dokumen sehingga dia juga beranggapan bahwa tindakannya bukan hanya dia melakukan sendiri, tetapi orang lain juga.

- Pelaku juga beranggapan barang yang dipinjamkan pada seseorang suatu saat bisa di kembalikan, meskipun barang tersebut belum tahu kapan barang 
tersebut bisa dikembalikannya dan pemilik tersebut kapan meminta barang yang dipinjaminya.

\section{Kesimpulan}

Berdasarkan hasil penelitian tentang faktor-faktor yang mempengaruhi tindak kecurangan yang dilakukan oleh mahasiswa adalah karena tekanan baik yang berupa finansial dan non finansial. Sedangkan dari dari sudut pandang faktor opportunity mereka melakukan tindakan kecurangan tersebut dikarenakan kurangnya pengawasan di organisasi atau kepanitiaan di mana mereka terlibat dan karena para pelaku fraud sudah memahami kondisi di lingkungan organisasi atau kegiatan kepanitiaan sehingga mereka sudah mengetahui kelemahan sistem yang diterapkan. Dari sudut pandang pembenaran/rasionalisasi mereka beranggapan bahwa barang yang mereka pinjam suatu saat akan dikembalikan dan mereka beranggapan bahwa tindakan yang mereka lakukan seperti pemalsuan nota transaksi itu adalah sah-sah saja karena mereka merasa teman-teman yang pernah terlibat di dalam organisasi atau suatu kepanitiaan juga melakukan hal serupa.

\section{Keterbatasan}

Keterbatasan dari penelitian ini adalah bahwa jumlah sampel yang terambil mungkin belum mewakili semua mahasiswa yang terlibat langsung dalam organisasi atau kepanitiaan suatu kegiatan baik di dalam maupun di luar lingkungan Universitas Islam Indonesia dan dalam penggalian data-data mengenai tindakan fraud tidak disertai dengan metode pengumpulan data lainnya seperti wawancara secara langsung yang akan menjadikan data-data yang terkumpul akan lebih valid. Disamping itu, responden dalam penelitian ini tidak dibedakan atas responden yang pernah atau sedang terlibat kepanitiaan atau organisasi di lingkungan Universitas Islam Indonesia atau di luar lingkungan Universitas Islam Indonesia.

\section{Saran}

Untuk penelitian selanjutnya sebaiknya responden diambil dengan lingkup yang lebih luas dan metode pengumpulan data yang sebaiknya dilakukan disamping dengan menyebarkan kuesioner, juga dilakukan dengan melakukan wawancara langsung sehingga data-data yang terkumpul akan lebih valid. 


\section{DAFTAR PUSTAKA}

American Institute of Certified Public Accountants, Statements of accounting Principles board No.4, United State of America, 1970.

Buchoff A, Thomas, Employee Fraud: Perpetrators and their, Journal of Forensic Accounting, North Dakota State University, 2001.

Callahan, David, Rational Cheating: Everybody's Doing It, Journal of Forensic Accounting, 2004.

Conan C, Albrecht Et, Al, Fraud Examination, A Part of Cengage Learning, Third Editon, South Western, 2009,

DiGabriele, James A, Implications of Regulatory Prescriptions \& Audit Standards on the Evolution of Forensic Accounting in the Audit Process, Montclair State University, Amerika, 2008.

Ditama binbangkum, Fraud (kecurangan), Journal of Forensic Accounting, Sie Infokum, 2008.

Maslow, Abraham H,A Theory of Human Motivation, dalam Phycbology Review,1943.

Pusdikatlawas BPKP, Audit Forensik, diakses 22 November 2011, di http://pusdiklatwas.bpkp.go.id/pusdiklatwas/halaman/show/44, 2008.

Riduan Simanjuntak; Ak., MBA, CISA, CIA; Kecurangan: Pengertian dan Pencegahan; diunduh dari

www.asei.co.id/internal/docs/Asei-Kecurangan.doc; tanggal 14 Oktober 2011

Saleh, Julianto, Hirarki Kebutuhan Menurut Abraham Maslow, Journal Motivation and Personalty, Vol 7 No.7, 2003.

Satori, Djam'an dan Aan Komariah, Metodologi Penelitian Kualitatif, Alfabeta, Bandung, 2009.

Singleton, Tommie and Aaron, Fraud Auditing and Forensic Accounting. Third Edition, John Wiley \&Sons, Inc, New Jersey, 2006.

Silvertone, Hovard, Michael Sheetz, Forensic Accounting and Fraud Investigation For Non-experts, John Wiley \& Sons, Inc., United States of America, 2004.

Sugiyono, Memahami Penelitian Kualitatif, Alfabeta, Bandung, 2009.

Suhermadi, Bambang, Management Fraud, di unduh dari

http://internal.dsuc.co.id/management-fraud, Submitted by Bambang Suhermadi on Fri, 2006.

Tuanakotta , Theodorus M, Akuntansi Forensik dan Audit Investigasi, Lembaga

Penerbit Fakultas Ekonomi Universitas Indonesia, Jakarta, 2007. , Menghitung Kerugian Negara, Salemba Empat, Jakarta, 2009. 
Ulinski, Michael, An Analysis of Small Company Frauds and Implications for Auditors In Detecting Frauds, Journal of Forensic Accounting of Pace University, 2007

Wilopo, Analisis Faktor-Faktor yang Berpengaruh Terhadap Kecenderungan Kecurangan Akuntansi, Journal of Forensic Accounting, STIE Perbanas, 2006. 